\title{
The National Library Of Uzbekistan As A Digital Humanities Center In Uzbekistan
}

\author{
Zumrad Rakhmankulova \\ Phd Of History, Associate Professor, Department Of Source Studies And Archival Studies, \\ National University Of Uzbekistan
}

Copyright: Original content from this work may be used under the terms of the creative commons attributes 4.0 licence.

\section{ABSTRACT}

This article analyzes data on Digital Humanitarian center in Uzbekistan and their achievements. Today, Digital Humanities is one of the fastest-growing fields not only in Uzbekistan but also in the world. The article also analyzes information on the creation of digital copies of historical archival documents, museums and their exhibits in large Digital Humanitarian Centre of the A. Navai National Library of Uzbekistan. Also classified interesting materials about modern technical equipment and problems using electronic libraries.

\section{KEYWORDS}

Digital humanities, Republic of Uzbekistan, e-history, National Library of Uzbekistan, cultural heritage, electronic resources, historical, cultural heritage,online service, bibliographic records, QR-code, wi-fi zones, infokiosks, department of DH, DH Center.

\section{INTRODUCTION}

Nowadays it is difficult to achieve the rapid introduction of innovations and technologies without deep modernization of the economy at a time of stabilization in the Republic of Uzbekistan. This requires first of all the integration of education, science and industry and the introduction of a number of specific technical solutions. The Government of the Republic of Uzbekistan has implemented a number of reforms in this work, and many laws and regulations are being adopted [1]. 
Digital Humanities (DH) is one of the fastest growing industries in the developed world, with the introduction of digital and information and communication technologies in the social sciences and education in modern times.

The DH Centre's main tasks include the organization of scientific schools, scientific seminars, digital publications, electronic systems analysis and geo-information systems, computer literary texts, and the provision of digital literature and basic data for humanitarian research [2].

In addition to the term $\mathrm{DH}$, the term ehumanities, e-Science, e-history can be found on many websites, research articles, research projects and more. DH routes are available at universities in the United States, Canada, Australia, France, the Netherlands, the United Kingdom, and other countries[3]. For example: Cultures Anglophones et Technologies de I'Information (University of Sorbonne, Paris, France), Centre Informatique de Philosophie \& Lettres (University of Liege, Belgium), Göttingen Centre for Digital Humanities (Georg-August-Universität Göttingen, Germany), Utrecht Digital Humanities Lab (University of Utrecht, Netherlands) and others[4].

Today there are more than 130 ethnic groups in the Republic of Uzbekistan, and their awareness of tolerance plays an important role in social, political and cultural life. By implementing innovative techniques in this area, its efficiency can be achieved with great success.

\section{RESEARCH METHODOLOGY}

As a result of the development and implementation of modern technologies in the world community, there is a growing demand for digital resources and resources for society. Establishing and enhancing the role of the $\mathrm{DH}$ Centers is one of the pressing issues in the Republic of Uzbekistan. The role of the "Uzarxiv"Agency of the Republic of Uzbekistan, "Uzbekmuzey" and the National Library of Uzbekistan as a DH Center in providing the public with digital resources and information is growing today.

As a result of many discussions by experts in digital technology and the social sciences, the emergence of a new DH in the US and the UK has emerged in the mid-twentieth century. External factors in this area include digital technologies in search of scientific and creative industries, electronic libraries, museum collections, data exchange and data access systems [5]. One of the key factors is the management of the educational process. In particular, internal factors are directly reflected in the use of digital technologies and are now used as a methodological tool in the development of the humanities.

The main purpose of this study is the development of one of the currently developing directions: Digital Humanities Agency of Uzbekistan, National Museums of Uzbekistan and the Alisher Navoi National Library of Uzbekistan, and to provide information on the processes of creating digital copies of cultural heritage sites, establishing a system for prompt access to books, archives and historical museum collections in these centers.

The sources used in research coverage can be classified into several groups:

1. The legislation of the Republic of Uzbekistan, which is of great importance in the development of the direction of Ditital Humanities in Uzbekistan;

2. Scientific articles; 


\section{Dissertations;}

4. Reports;

5. Electronic resources.

The first type of sources include not only the laws that are the basis for the development of the Republic of Uzbekistan's Ditital Humanities, but also the legislative acts, resolutions and decrees.

The second type of resources should be scientific articles written in this area. In particular, the structure and hypotheses of this article were determined from the scientific works of D.Zorich, G.V.Mojayeva, P.N.Mojayeva-Renya, V.A. Serbin, I.E.Khvorova.

The third type of source included Sh.Miralieva's thesis on Virtual Museums, and a monograph on the history of archival work of $Z$. Rakhmonkulova [6], in Uzbekistan, which was used as a source as well as Sh.Choriev [7], X.Buriyeva [8], A.Nazarov [9] are analyzed on their research works about some historical archive documents and their digitization issues.

The next type of source is critical to this research, which is the official, quarterly, and annual reports of the Digital Humanities Centers for 2016, 2017, 2018.

Currently, with the increasing importance of internet resources, statistical and digital data have been used extensively on websites.

This study, firstly, analyzed the history and current activities of the aforementioned Digital Humanities Center. Secondly, the Center official websites, which have been the main source for the article, have been analyzed their reports based on statistical, comparative analysis, and summarized the results of these centers' work on Digital Humanities. For convenience of the article's users, the study used a diagram method to analyze several years of statistical data. Graphical representation of statistical data is important for specialists in this field and other industry professionals in providing more accurate and understandable information.

\section{MAINBODY}

\section{NATIONAL LIBRARY OF UZBEKISTAN - AS A NATIONAL DH CENTER}

Libraries play an important role in increasing the spiritual awareness of the society and are an important center for the preservation of ancient cultural values. The National Library is a state-run information center, which is one of the main tools for the intellectual development of the nation. The difference between the national libraries and the public libraries is that they can store and store books published in the country and abroad, have a relatively large fund, and do not use books outside the library. Today there are many National Libraries in the UK, USA, France, China and other countries.

The Alisher Navoi National Library of Uzbekistan also plays an important role in the cultural life of Uzbekistan's population. The library, which has more than a century of history, was opened in May 1870 as the Tashkent Public Library. The Ministry of Education, the Academy of Sciences, the Public Library, the Geographical Society and the Russian General Staff have contributed to the creation of the Fund and donated books and publications from their foundations. In May 1870 , more than 2,200 volumes ( 1,200 titles) of literature were collected and the foundation of the library was established.

The Tashkent Public Library has to collect and store literature on various fields of science, 
first and foremost of the country and neighboring countries. The famous Russian bibliographer V.I.Mejov has been recruited to supplement the library's lore fund. He organized a collection of Turkestan materials for the Tashkent Public Library and laid the foundations in a scientific collection known as the "Turkestan Collection".

On April 12, 2002 the Resolution of the Cabinet of Ministers of the Republic of Uzbekistan "On the Establishment of the National Library of Uzbekistan named after Alisher Navoi" was issued. According to the decision, the status of the library is defined as the main state treasury of national and foreign literature, scientific research, methodological work and coordination in the field of library science, bibliography and book studies.

In accordance with the Decree of the First President of the Republic of Uzbekistan "On measures for the organization of activities of the National Library of Uzbekistan Information Resource Center named after Alisher Navoi" of March 20, 2012, the library structure was updated and improved service, expanded the range of tasks. It allows using information and communication technologies to meet the educational, spiritual, educational and cultural needs of the population, especially the youth.

For the purpose of preserving the scientific, historical, cultural and educational heritage of our people, further demonstrating its great contribution to the world civilization, bringing to the future generations the unique works, manuscripts and rare publications of our ancestors. Organization of work on the state scale, beginning with the adoption of the Resolution of the Cabinet of Ministers of the Republic of Uzbekistan dated August 9, 2012 №202 “On measures to ensure the safety, systematic reproduction and enrichment of rare, rare and unique publications".

This is an opportunity for The resolution provides for the electronic transfer of ancient manuscripts and rare books stored in information and library facilities, museums, as well as the purchase of many old manuscripts, ancient and rare books, and sources. Adoption of the Program on implementation of modern technologies, restoration and system reproduction as a priority.

In order to effectively organize the above tasks, the creation of an electronic catalog of ancient manuscripts and rare books, now stored in public libraries, museums, archives, as well as an electronic catalog of rare books available in the National Library of Uzbekistan. Identification and creation of a full-text electronic database of these publications is underway.

The National Library of Uzbekistan has stateof-the-art facilities and equipment for 13 highlevel reading rooms for 800 places.

Open funds created in reading rooms “Uzbekistan”, “Adolat”, “Istiqbol”, “Jahon”, "Tafakkur" became one of the most comfortable conditions for readers in the new building. The open position of the fund allows the user to easily search and order the books they need on the bookshelves, as well as to get acquainted with the newly acquired books in the library.

The library is implementing seven technical projects in 2013-2014 to promote the rich scientific literature in library collections and to provide remote user service, online services, and convenience of users of library services. In particular, the online service "Issuance of ISBN, ISSN and UDC, KBK" numbers, "Automation of 
the process of creation, storage and precise presentation of rare editions and manuscripts", automated statistical reporting of journals", "Unified Database for Dissertation and Research ", "Personal Cabinet", "Image Catalog”[10].

Today, the National Library also acts as a coordinating and methodological center for all information and library institutions in the country. The Republican methodical council, established at the library, is engaged in the development of recommendations for improving the activities of libraries through the widespread introduction of information and communication technologies, exemplary regulations for individual libraries, methodological bibliographic manuals and other targeted documents. National standards of information and library activity regulating relations in this area have been developed.

The Republican National Library of Uzbekistan operates in accordance with the legislation of the Republic of Uzbekistan and its Charter. The Republican Integrated Electronic Directory Center was established in accordance with the Decree of the President of the Republic of Uzbekistan dated February 23, 2011 "On measures for further development of information and library and information resources on the basis of information and communication technologies in 2011-2015".

Republican Unified Electronic Directory Center:

- Collection of bibliographic records created in all information and library institutions throughout the Republic and formation of a unified electronic catalog of the Republic of Uzbekistan.

- Editing electronic bibliographic records from the National Library of Uzbekistan and other information and library institutions;
- Interchange of electronic bibliographic records in cooperation with electronic catalogs of leading foreign libraries;

- Ensure the standardized collection of bibliographic records.

\section{DEPARTMENTS OF THE CENTER:}

- The main task of the cataloging and editing department is to avoid duplication in improving the quality of bibliographic records, as well as editing and controlling the entries. There are 5 specialists in the department.

- The main task of the External Relations and Maintenance Department is to establish active communications between information library and bibliographic records, as well as to control the storage of electronic records and unauthorized access to archived data.

According to the 2019 library statistics, the total fund of the National Library is 7,357,192, of which the print fund has increased by 6,867 copies, and the resources available in electronic format have reached 604,691. The total number of registered users in the National Library is 223,439 , and in the reporting period there were 6,310 registered users. Over the past period, the total number of visits was 208,654, including: library visitors - 179 188, library users - 29 466, booking - 1198710 copies. 124,615 references were received by sources. The creation of electronic resources during the reporting period on automation processes, including filling up an electronic catalog, 1084 bibliographic records were included in the “UzNEL” program.

The total number of bibliographic records in the electronic catalog is 675,554 . Work on the creation of electronic copies of the most popular and new publications through 
scanning and duplication services was carried out, with a total of 5,890 publications in full. Including books - 2000, abstracts - 700, manuscripts, rare and especially valuable publications - 90, newspapers - 3100 copies [11]. From 2016 the National Library has been subscribing to the National Database Full-text Database. Currently, there are 120 libraries of research institutes under the Academy of Sciences of the Republic, information resource centers of the Ministry of Higher Education, libraries of state authorities and administration, information and library centers of the Republic of Karakalpakistan, Tashkent city and regions, etc. and remote servicing of organizations and leading foreign information and library resources. The National Library of Uzbekistan has launched the qr. natlib.uz system to enable young people to read books and download electronic copies of modern mobile devices by placing QR-code boards in public places, railway stations and waiting rooms, bus stops. The main features of the qr. natlib.uz system, which allow you to read and download e-books on mobile devices:

- Support for various mobile device platforms (Opera, Google Chrome, Firefox, Safari);

- Download e-books in pdf, doc, fb2 format;

- maintaining the statistics of downloaded ebooks; - to maintain a common database of e-books;

- Search by book title, author and tag;

- Ensuring full operation of the TAS-IX system;

- Creation of QR codes to increase accessibility of mobile devices. To date, over 50 e-books have been downloaded to kr.natlib.uz, the books have been downloaded 1199 times by users, and 2854 have been read directly from the system;

- Contact information of the management of the National library of the Republic of
Uzbekistan on the Open Data Portal of the Republic of Uzbekistan and their admission time - Information about the location and geological area of the National Library of Uzbekistan;

- Main indicators and statistical data of the National Library of Uzbekistan;

- Structure, Address and Contact Information at the National Library of Uzbekistan;

- Information about large information and library institutions in the Republic of Uzbekistan;

- Cooperation of the library with other organizations;

- Information about international cooperation of the library is being published [12]. The National Library of Uzbekistan has WI-FI zones, which allow users to use modern computers and have access to modern methods of digital and large-scale telecommunications.

There are 220 terminals and 9 infokiosks for users of the National Library of Uzbekistan. Including information about the National Library of Uzbekistan in 4 infokiosks, 2 infokiosks online access to 2,200 newspapers in 54 languages in 97 countries on Librarypressdisplay.com, 2 audio books and 3D tours throughout the library, 1 The information on the Wyeb-Automated information-library system is placed in the infokiosks. In addition, on May 1, 2018, the National Library of Uzbekistan hosted a meeting for users of paid services in the library through the systems "CLICK" and "Payme".

Work is underway to access WWW.UZ site rating website through the National Library of Uzbekistan website and access TULIP (Triple U Library Information Portal) through ID.GOV.UZ. Within the framework of the project "National General Electronic Library", 
the "Management" group will meet in Seoul, South Korea on July 8-12 to discuss the e-library system of the Republic of Korea and its activities. On July 22, a total of 17 managers and staff participated in the training. On August 2728, 2018 the National Library of Uzbekistan will host 14 information-library centers of the Republic of Uzbekistan, National Library of the Academy of Sciences of the Republic of Uzbekistan on the project "National Electronic Electronic Library".

Seminars for the specialists of the Pedagogical Library, Tashkent State Technical University and information-resource centers of the National University of Uzbekistan named after Mirzo Ulugbek. The seminar also included training and practice on the UzNEL system (monographs and periodicals), book delivery (user management and book delivery and return), and the UzNEL Web system. Within the framework of the project of the National Electronic Library, LG CNS representatives have completed the reconstruction of the building, and the necessary equipment, installation and installation of the equipment are being carried out.

Within the framework of the project "National Electronic Library" the following training courses were conducted:

- On July 9-22, 2018, in Seoul, Republic of Korea, participated in training courses;
- From August 27, 2018 to November 1, 2018, there will be training courses on Digital Technology, Information Technology Infrastructure, Multimedia Center and Software [13].

In conclusion, the National Library of Uzbekistan plays an important role in the cultural life of Uzbekistan's population. The library is the main state treasury of national and foreign literature, scientific research, methodical work and coordination of scientific activity in the field of library science, bibliography and book studies.

It has 13 training rooms with 800 seats, equipped with modern equipment and machinery. The library is a digital library, which is a coordinating and methodological center for all information and library institutions of the Republic.

The total fund of the National Library is $7,357,192$ copies, of which the print fund is 6,867 copies, and the total number of digital resources is 604,691. From the National Library of $\mathrm{DH}$ to the third quarter of 2019, there were a total of 223,439 registered users, of which 208,654 visitors visited, and its website used 29,446 readers. There are 220 terminals for library users and 9 infokiosks in the database, read online for 2,200 newspapers in 54 different languages in 97 countries, audio books and 3D travel across the library, WebAutomated Information Library System provided to users.

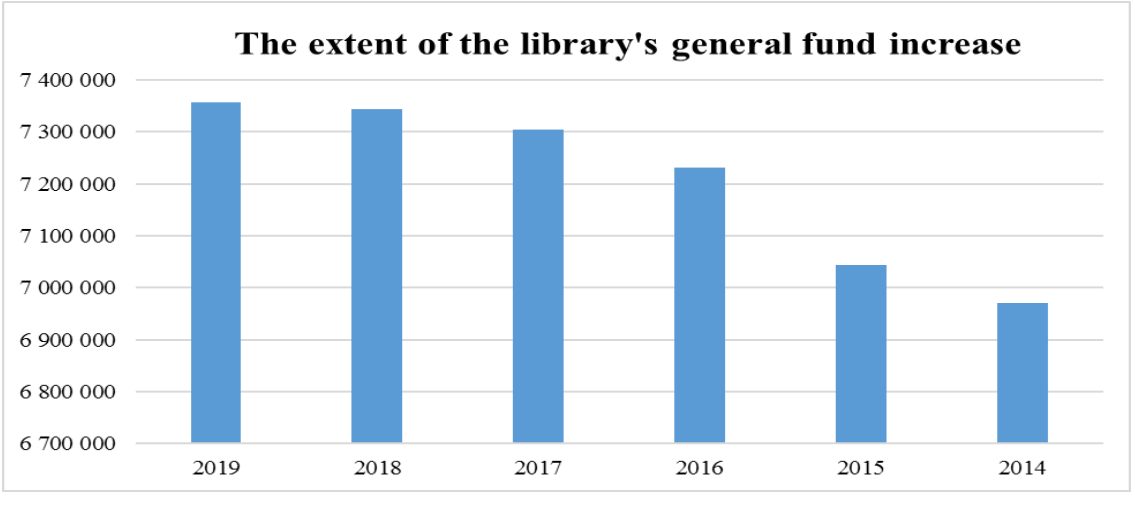




\section{CONCLUSION}

The emergence of a new $\mathrm{DH}$ pathway is essential for the development of new scientific and research findings.

In Uzbekistan, DH Center of the National Libraries of Uzbekistan are growing in the country.

The total fund of the National Library is $7,357,192$ copies, of which the print fund is 6,867 copies, and the total number of digital resources is 604,691 . A total of 223,439 users have been registered from the $\mathrm{DH}$ National Library by the third quarter of 2019, and its website has been used by 29,446 readers. There are 220 terminals for library users and 9 infokiosks in the database, read online for 2,200 newspapers in 54 different languages in 97 countries, audio books and 3D travel across the library, Web-Automated Information Library System provided to users.

In Uzbekistan, there are some problems with increasing the role of $\mathrm{DH}$ centers in their place. In particular, in the higher educational institutions of Uzbekistan the department of $\mathrm{DH}$, bachelor's and master's degrees in "Humanitarian Informatics" are not organized. The DH Digital Humanities Research Workshop does not set up any special research. Training of qualified DH personnel can help DH Centers achieve more targeted and effective results.

\section{REFERENCES}

1. Decree of the President of the Republic of Uzbekistan dated November 29, 2017 № PD-5264 "On the establishment of the Ministry of Innavative Development of the Republic of Uzbekistan"; Decree of the President of the Republic of Uzbekistan dated November 30, 2017 № PD-3416 “On the organization of activity of the Ministry of Innovative Development of the Republic of Uzbekistan"; Decree of the President of the Republic of Uzbekistan № PD-3899 "On measures to improve the efficiency of the integration of scientific and innovative activities", № PD-3682 “On measures to further improve the system of practical implementation of innovative idas, technologies and projects"; Decree of the President of the Republic of Uzbekistan № PD-3698 “On additional measures to improve the mechanisms for introducing innovations in sectors and sectors pf the economy"; Decree of the President of the Republic of Uzbekistan PD-3855 "On additional measures to improve the efficiency of commercialization of scientific and scientific-technical activities" and etc..

2. Golenok M.P. Digital humanities: a problem field and development prospects [Electronic resource] / M.P.Golenok, H.O.Osipova // Scientific Review: electron journal. - 2018. - № 1. -P.4

3. Mozhaeva G.V., Mozhaeva-Renya P.N., Serbin V.A. Digital humanities: organizational forms and research infrastructure // Bulletin of Tomsk State University. 2014. № 389. P.73.

4. https://eadh.org/education/digitalhumanities-centres

5. Golenok M.P. Digital humanities: a problem field and development prospects [Electronic resource] / M.P.Golenok, H.O.Osipova // Scientific Review: electron journal. - 2018. - № 1. -P. 3-5

6. Rakhmankulova Z., Choriev Sh., Yusupova D., Muminov O. The Historiography Of The Relations Between Central Asian Khanates And Ottoman Empire In The 19th And At The Beginning Of The 2oth Centuries / INTERNATIONAL JOURNAL OF SCIENTIFIC 
\& TECHNOLOGY RESEARCH VOLUME 9, ISSUE 02, FEBRUARY 2020 ISSN 2277-8616

7. Choriev, S. S. (2019). The history of Baltic nation diaspora in Uzbekistan. ISJTheoretical\&AppliedScience, 02 (70), 19-25. Choriev SS (2017) CLASSIFICATION OF THE Turkestan ASSR documentation in the Central State Archive of the Republic of Uzbekistan. ISJ Theoretical \& Applied Science, 12 (56): 50-54.

8. Khayriya Burieva. Toponyms of Tashkent as a factor of reflection of historical processes (1917 - 1980). 3-4. American Journal of Research P. 143-151 (2019).

9. Nazarov A. (2020) Scientific societies in the Turkestan governorate-general as an instrument of colonial statehood (archival source study) Journal of Critical Reviews ISSN- 2394-5125 Vol 7, Issue 7, 2020 http://dx.doi.org/10.31838/jcr.07.07.195

10. Guidelines for the electronic copying of archival documents and management of the resulting information array. [Electronic resource] URL: http://archives.ru/documents/rekomend el-copyarchival-documents/razdel-2.shtml (accessed: 13.05.2016).

11. Miralieva Sh. World experience in creating virtual museums and their development prospects in Uzbekistan. PhD diss.. Tashkent, 2019. - P.8-25

12. https://www.natlib.uz/

13. https://www.natlib.uz/

14. Report of the National Library of Uzbekistan named after Alisher Navoi for the 1st quarter of 2019.

15. Rakhmankulova, Z. B., \& Rakhmankulova, M. B. (2019). SOME PECULIARITIES OF THE BOOKBINDING IN TEMURID'S EPOCH. Theoretical \& Applied Science, (10), 266272.

16. Rahmankulova Z. Ottoman Empire and the political activity of England in Central Asia in the 19 th century. European Society for
Central Asian Studies Tenth Conference. Central Asia Sharing Experiences and Prospects. Ankara. 2007.

17. Rahmankulova Z. Rejuvenating silkroad: past present and future of TurkeyUzbekistan reletions. 1 st edition Istanbul Sabahattin Zaim university publications. Turkey. 2019. - pp. 185-186

18. Rahmokulova Z. Birinci dunya savasi ve Turkistan. Uluslararasi Asya ve Africa calismalari kongresi. 38.ICANAS (bildiri ozetleri). Ankara. 2007. p.304 